\title{
THE CENTRAL PORTUGAL LATE BRONZE AGE: CONTRIBUTION TO A STUDY ON REGIONAL ETHNOGENESIS *
}

\author{
J. C. DE SENNA-MARTINEZ**
}

Abstract

We discuss the ethnogenesis of the Central Portugal Late Bronze Age populations arguing that they correlate well with the later descriptions of the Lusitanians.

The economic result of the local agricultural produce, pastoralism and wild fruits collecting was not enough by itself to support an economic growth of these societies that was capable to allow more than a small amount of wealth concentration. Accordingly, we think that social elite's genesis and development in the local Late Bronze Age Groups is based on a «wealth finance» system for which the control of metal's production and circulation provides the means.

Also matrimonial exchanges could well be behind a network of elite alliances thus accounting for the quick diffusion of metallurgical technologies and models and their local reproduction.

Peripheral to the expansion of the Mediterranean network of commerce in the LX/VIII centuries BC, the interior areas of this system are very vulnerable to any change in the metal commerce networks. This will determine their demise during the VI century BC as a result of the temporary collapse of the Mediterranean-Atlantic commerce network. The exception is the Atlantic Estremadura where the more diversified economy and the cosmopolitanism of its incipient urbes will allow a steady development during the Iron Age.

So both the characterisation of the local Late Bronze Age Groups and their subsequent evolution correspond well with the description by the classic authors of the Lusitanians and the «two Lusitanias» allowing us to argue that their ethnogenesis goes back at least to the Late Bronze Age.

Key-words: Lusitanian Ethnogenesis, Central Portugal Late Bronze Age

Resumo

O Bronze Final no Centro de Portugal. Um contributo para o estudo da etnogénese regional — Tenta-se aqui uma primeira análise da etnogénese das populações que, no Bronze Final das Beiras e Estremadura portuguesas, pensamos ancestrais dos Lusitanos dos autores clássicos.

Defendemos que o nivel de complexidade sociocultural atingido por estas comunidades assenta num sistema de «Wealth Finance» uma vez que a produtividade ao nível da subsistência, tendo ainda como elemento importante actividades recolectoras, não parece ter ultrapassado limiares de acumulação e crescimento baixos e incapazes por si sós de permitirem um crescimento económico sustentado e o surgimento de elites.

Pensamos ainda que um sistema de alianças, provavelmente incluindo trocas matrimoniais, regularia a circulação de pessoas e bens com incidência, nomeadamente, na difusão das tecnologias e modelos metálicos e sua rápida reprodução a nível local.

Funcionando periféricamente em relação ao interlaçar, a partir do see. VIII AC, das redes de contacto atlântica e mediterrânea, a vulnerabilidade destes sistemas a alterações nos circuitos de troca de metais torná-los-á incapazes de resistirem à crise do séc.VI AC, com a excepção da área estremenha onde o cosmopolitismo das urbes emergentes e a economia mais diversificada permitirão uma continuidade de desenvolvimento durante a Idade do Ferro.

Quer a caracterização deste mundo do Bronze Final Beirão e Estremenho, quer a sua evolução, correspondem bem á descrição que os autores clássicos fazem das «duas Lusitânias» e dos Lusitanos pelo que defendemos ser a respectiva etnogénese um processo remontável ao Bronze Final.

Palavras-chave: Etnogénese dos Lusitanos, Bronze Final do Centro de Portugal

1. THE RECENT PREHISTORY OF CENTRAL

PORTUGAL: SOME ARCHAEOLOGICAL FACTS

We raised before (SENNA-MARTINEZ, 1995a) the question of why we don't have in the culture groups of Beira Alta, from the fourth to second millennium BC, with one possible exception', a historical trajectory similar to the ones in the Portuguese Estremadura and Southwest and resulting in complex settlement systems.

Despite the lack of adequate archaeological investigation this is also the kind of image we get for the socalled Portuguese Beira Baixa during the Neolithic and Calcolithic.

But, nevertheless, in a much smaller scale. For the problems concerning the Castro de Santiago Fades see: SENNA-MARTINEZ, 1989, 1994b and 1995a; VALERA, 1992, 1993, 1994 and 1997. Also for the Early/Middle Bronze Age the same picture is gradually emerging for the Middle and High Mondego's Basin, where for just one very small fortified settlement (Fraga da Pena, see VALERA, 1994) we know a few others that maintain the kind of lowland unimpressive geographical location of the ones known from the fourth and third millennium $\mathrm{BC}$ communities.

* Paper presented at «II Reunión Internacional sobre los Orígenes de la Civilización en la Europa Mediterrânica», organised by Universidade Internacional de Andaluzia (Universidade de Jaén), Baeza, 18th to 20th December 1995.

** Instituto de Arqueologia da Faculdade de Letras de Lisboa, 1699 Lisboa Codex - Portugal. 
For Beira Alta we argued as the main explanation the lack of a local stable and reliable food source as the basis for staple finance, as in the Southwest, together with the lack of a rich and diversified agricultural economy that could support the emergence of wealth finance as in the Estremadura (GILMAN, 1987). Actually, a small increase in social complexity eventually took place, mainly in the Late Copper Age and especially during the transition to the Bronze Age, as it is revealed by the appearance of beakers and the first metal artefacts (SENNA-MARTINEZ, 1994b) as well as the development of a system for volume measurement that arose in the Early/Middle Bronze Age (SENNA-MARTINEZ, GARCIA \& ROSA 1984; SENNA-MARTINEZ, 1993c).

We suspect that the development of pastoralism with the advent of transumance can be one of the economic factors behind such events together with possible networks of raw materials exchange (SENNAMARTINEZ, 1994e). Nevertheless, the continued use of the collective megalithic necropoli during most of the second millennium surely indicates conservative societies.

Now we'1l discuss the reasons we think generated the profound changes in this status quo and that come into play by the last centuries of the second millennium $B C$ and the first quarter of the first coinciding with the advent of the Late Bronze Age.

The main transformation suffered by Late Bronze Age studies in Portugal during the last decade consists of a change in approach from metal hoards to habitat sites, their material culture, economic indicators and spatial location. This is particularly true for the northern half of the country (The Beiras, Minho and Trásos-Montes).

In fact, the Late Bronze Age constitutes the first time in the Portuguese Beiras ${ }^{2}$ when we have some evidence for the development of a hierarchical settlement system with small «central places», all of them with a dominant location and regularly spaced, and subsidiary sites in between (SENNA-MARTINEZ, 1989a, p. 690-691 andfig.'s 3.3-3.4, 1994a; SENNA-MARTINEZ \& COELHO, 1994; SENNA-MARTINEZ \& NUNES, 1993; SENNA-MARTINEZ, ROCHA \& RAMOS, 1993; SENNAMARTINEZ, et al, 1993a and 1993b; VILAÇA, 1995).

Several radiocarbon dates from recently excavated sites in both areas (SENNA-MARTINEZ, 1994a; VAZ, in press; VILAÇA, 1995) allow us to say that at least some of the local Late Bronze Age central settlements were already established in the last two centuries of the second millennium BC (Table I). They occupied strong dominant positions, enabling them to visually control large parts of the regions and/or important crossing points in the mountains and river systems
(SENNA-MARTINEZ，1989，p.644-645, 651 and 1994a; VILAÇA, 1995).

In Beira Alta all the main sites from this phase that have been excavated, besides tbteir natural defensive positions, have dry stone walls that complement them (KALB, 1978; SENNA-MARTINEZ, 1989a; SENNA-MARTINEZ \& COELHO, 1994; SILVA, CORREIA \& VAZ, 1984 and 1985). In Beira Baixa the picture is much the same but for the lack of walls complementing de dominant geographical position of settlements (VILAÇA, 1995).

In Beira Alta the central settlements have areas between 1.5 and 0.5 ha, measuring the smaller ones less than $100 \mathrm{~m}^{2}$ (Table II - SENNA-MARTINEZ, 1994a: 216), while the available data for Beira Baixa show only one case with 0.7 ha, the average lying between 0.2 and 0.28 ha (Table II - VILAÇA, 1995, p.251-253).

Looking at the data displayed in Table II, it is clear that very few sites in Beira Alta would have had more than 500 people, the main bulk of them laying probably between two and three hundred, while for Beira Baixa the average would be from 150 to two hundred people.

To understand the meaning of these numbers it is useful to remember that the population of the city of Viseu, according to the AD 1527-1532 «numeramento», was 2295, while Seia had a little more then 500 people. The population density for the area of the Mondego Basin would have been of about 5 inhabitants/Km² (MARTINS, 1940). If we try a calculation for the same area during Late Bronze Age times, based on the data of Table I, we would get a number ranging from 1 to 2.5 inhabitants $/ \mathrm{Km}^{2}$, which looks acceptable.

One consequence of this data is that each of the «central places» together with the few scattered households surrounding each of them would hardly be self-sufficient in terms of social reproduction.

The houses inside these settlements seem to have been simple huts made of wood branches, sometimes with low wall foundations of dry stone. Fireplaces, either inside or outside them, frequently consist of a clay surface layered over a foundation of sherds and small stones. Loom weights on pebbles (common to both regions) and the probable vertical loom structure found inside one hut at Cabeço do Crasto de S. Romão bears witness to textile production (SENNA-MARTINEZ, 1994a; VILAÇA, 1995).

Either in Beira Alta or in Beira Baixa, the regional particularities aside, pottery can be divided into two different production classes: Fine wares (which in Beira Alta represent about $40 \%$ of the vessels found) usually with stroke burnish finishing and sometimes

For a description of Beira Alta and Beira Baixa geographical and geological conditions see respectively SENNA-MARTINEZ, 1995a and VILAÇA, 1995. 
decorated with engraved lines in Beira Alta or also with «ornatos branidos» mainly in Beira Baixa; and coarser wares (which in Beira Alta represent about $60 \%$ of the vessels found) that we think are mainly for storage and cooking, and are frequently decorated on the rim by incision and nail or finger impressions and sometimes present «cepillo» treatment in the neck and body of vessels.
It is important to stress the close identity of pottery production between the sites already analysed in each of the areas (SENNA-MARTINEZ, 1993d; VILAÇA, 1995, p. 270-309).

Some of the pottery types present as well as the continued use of sickle blades, groundstone adzes, and saddle querns seem to indicate the possibility of a continuity between this horizon and the local Early /

TABLE I - ${ }^{14} \mathrm{C}$ Dates for Central Portugal Late Bronze Age

TABELA I - Datas de Radiocarbono para o Bronze Final do Centro de Portugal

\begin{tabular}{|c|c|c|c|}
\hline Site/Sítio & Reference/Ref. $^{\text {a }}$ & Date BP & Date cal AC $2 \phi^{3}$ \\
\hline
\end{tabular}

Beira Alta:

\begin{tabular}{|c|c|c|c|c|}
\hline \multirow{3}{*}{ C. C. S. Romão ${ }^{4}$} & \multirow{3}{*}{$\begin{array}{l}\mathrm{B}[16] \\
\mathrm{B}[25] \\
\mathrm{C}[105]\end{array}$} & ICEN - 197 & $2910 \pm 35$ & $1210-921$ \\
\hline & & ICEN - 824 & $2680 \pm 80$ & $1020-760$ \\
\hline & & ICEN - 199 & $2970 \pm 35$ & $1268-1043$ \\
\hline & B. Moura S. Romão ${ }^{4}$ & ICEN - 600 & $2770 \pm 90$ & $1160-790$ \\
\hline & & ICEN - 489 & $2960 \pm 50$ & $1313-1004$ \\
\hline & & ICEN - 486 & $2960 \pm 60$ & $1320-990$ \\
\hline & Castro de Santa Luzia ${ }^{4}$ & ICEN - 485 & $2920 \pm 180$ & $1530-770$ \\
\hline & & ICEN - 487 & $2810 \pm 100$ & $1250-800$ \\
\hline & C. S. ${ }^{\text {da Guia }}{ }^{4}$ & ICEN - 7484 & $2650 \pm 130$ & $1060-400$ \\
\hline & & Sac-1566 & $2930 \pm 60$ & $1310-926$ \\
\hline & Outeiro dos Catelos de Beijós & Sac-1539 & $2960 \pm 45$ & $1310-1009$ \\
\hline & & Sac-1524 & $2610 \pm 60$ & $814-888^{5}$ \\
\hline
\end{tabular}

Beira Baixa:

\begin{tabular}{|l|l|l|l|}
\hline Alegrios 6 & GrN - 16840 & $3055 \pm 35$ & $1405-1206$ \\
\hline \multirow{3}{*}{ Monte do Frade 6} & GrN - 19660 & $2805 \pm 15$ & $995-904$ \\
\cline { 2 - 4 } & ICEN - 971 & $2850 \pm 45$ & $1127-900$ \\
\cline { 2 - 4 } & ICEN - 969 & $2930 \pm 50$ & $1263-932$ \\
\cline { 2 - 4 } & ICEN - 970 & $2780 \pm 100$ & $1251-792$ \\
\hline \multirow{3}{*}{ Moreirinha $^{6}$} & ICEN - 834 & $2940 \pm 45$ & $1266-998$ \\
\cline { 2 - 4 } & ICEN - 835 & $2910 \pm 45$ & $1257-931$ \\
\cline { 2 - 4 } & GrN - 19659 & $2785 \pm 15$ & $977-857$ \\
\cline { 2 - 4 } & OxA - 4095 & $2780 \pm 70$ & $1117-805$ \\
\hline
\end{tabular}

Atlantic Estremadura:

\begin{tabular}{|l|l|l|l|}
\hline \multirow{5}{*}{ Tapada da Ajuda 7 } & ICEN - 100 & $3000 \pm 40$ & $1324-1113$ \\
\cline { 2 - 4 } & ICEN - 184 & $3000 \pm 100$ & $1430-930$ \\
\cline { 2 - 4 } & ICEN - 96 & $3090 \pm 50$ & $1446-1200$ \\
\cline { 2 - 4 } & ICEN - 97 & $3010 \pm 60$ & $1400-1050$ \\
\cline { 2 - 4 } & ICEN - 99 & $2980 \pm 50$ & $1319-1029$ \\
\hline
\end{tabular}

3 Calibrated according to Program CALIB, cf. Stutver \& ReImer, 1993.

4 cf. SenNa-MartinEZ, 1989 e 1994b.

5 Calibrated at $1 \mathbf{s}$, at $2 \mathrm{~s}$ it calibrates between $844-546 \mathrm{cf}$. SENNA-MARTINEZ, no prelo.

6 ef. VILACA, 1994.

7 cf. CARDOSO \& CARreira, 1993. 
TABLE-II - Estimated Areas and Populations for the principal Habitat Sites

TABELA-II - Áreas e Populações estimadas para os principais Sítios de Habitat

\begin{tabular}{|c|c|c|c|c|c|c|}
\hline \multirow{2}{*}{ Site } & \multirow{2}{*}{$\begin{array}{l}\text { Aproximate } \\
\text { Dimensions }\end{array}$} & \multirow{2}{*}{$\begin{array}{c}\text { Aproximate } \\
\text { area }\end{array}$} & \multicolumn{4}{|c|}{ Probable of inhabitants according to: } \\
\hline & & & Narroll-1* & Narroll-1* & Hassan** & hab/cab*** \\
\hline
\end{tabular}

Beira Alta (Baiões/Santa Luzia Group)

\begin{tabular}{|c|c|c|c|c|c|c|}
\hline Castro da Senhora da Guia & $165 \mathrm{~m} \times 95 \mathrm{~m}$ & $15675 \mathrm{~m}^{2}$ & 1568 & 2484 & 1320 & 784 \\
\hline Castro de Santa Luzia & $160 \mathrm{~m} \times 90 \mathrm{~m}$ & $14400 \mathrm{~m}^{2}$ & 1440 & 2246 & 1228 & 720 \\
\hline Cabeço do Castro de S. Romão & $125 \mathrm{~m} \times 40 \mathrm{~m}$ & $5000 \mathrm{~m}^{2}$ & 500 & 640 & 497 & 250 \\
\hline Castro da S. ${ }^{a}$ do Bom Sucesso & $130 \mathrm{~m} \times 40 \mathrm{~m}$ & $5200 \mathrm{~m}^{2}$ & 520 & 670 & 514 & 260 \\
\hline Castro de São Cosme & $140 \mathrm{~m} \times 40 \mathrm{~m}$ & $5600 \mathrm{~m}^{2}$ & 560 & 732 & 548 & 280 \\
\hline Outeiro dos Castelos de Beijós & $140 \mathrm{~m} \times 45 \mathrm{~m}$ & $6300 \mathrm{~m}^{2}$ & 630 & 842 & 606 & 315 \\
\hline Buraco da Moura de S. Romão & (3 «rooms») & $40 \mathrm{~m}^{2}$ & 4 & 2 & 8 & - \\
\hline Cabeço do Cucão & $2 \times 5 \mathrm{~m} \times 3 \mathrm{~m}$ & $30 \mathrm{~m}^{2}$ & 3 & 2 & 6 & - \\
\hline Malcata & circle $\mathrm{c} / \mathrm{r} \cong 4 \mathrm{~m}$ & $50 \mathrm{~m}^{2}$ & 5 & 3 & 10 & - \\
\hline
\end{tabular}

Beira Baixa

\begin{tabular}{|l|c|c|c|c|c|c|}
\hline Monte de S. Martinho & - & $7625 \mathrm{~m}^{2}$ & 763 & 1056 & 713 & 380 \\
\hline Castelo Velho do Caratão & - & $2400 \mathrm{~m}^{2}$ & 240 & 266 & 268 & 120 \\
\hline Moreirinha & - & $2850 \mathrm{~m}^{2}$ & 285 & 324 & 302 & 143 \\
\hline Alegrios & - & $2392 \mathrm{~m}^{2}$ & 239 & 256 & 120 \\
\hline Castelejo & - & $1975 \mathrm{~m}^{2}$ & 197 & 191 & 241 \\
\hline Monte do Frade & - & $126 \mathrm{~m}^{2}$ & 12 & 8 & 21 \\
\hline
\end{tabular}

* Narroll, 1962

** Hassan, 1981, p. 73

*** Data established according to the excavation results of Cabeço do Crasto de S. Romão and Outeiro dos Castelos de Beijós showing an average area of $100 \mathrm{~m}^{2}$ per habitational unit of 5 inhabitants.

***** Data according to VILAÇA, 1995, p. 251-253.

Middle Bronze Age ones, as the stratigraphy of the «Sala 20» of Buraco da Moura de S. Romão suggests for Beira Alta (SENNA-MARTINEZ, et ai, 1993a; SENNA-MARTINEZ \& VALERA, 1995).

Once again regionally there is strong evidence of renewed human impact on the environment, which the radiocarbon-dated pollen sequences from the peat bogs of Serra da Estrela allow us to situate as beginning already in the Middle Bronze Age, about 1550 $\mathrm{BC}$, at middle altitude zones (below $1500 \mathrm{~m}$ ) and with a later impact, about 1000 BC, at higher altitudes (KNAAP \& JANSSEN, 1991; KNAAP \& VAN LEEUWEN, 1994, p. 533).

Roughly speaking, this seems to show an intensification process with growing importance of cereal cultivation (probably mainly rye) together with transumance. Nevertheless, the data from Cabeço do Crasto de S. Romão (SENNA-MARTINEZ, 1989a, p. 200204, 669; 1994a) allow us to say that acom (Quercus sp. cf. robur) gathering still represents, at least in some mountain sites, an important part of the subsistence and a probable useful dietary complement in others as we find at Senhora da Guia (SILVA, 1976).

Acorn utilisation as a food source starts regionally in the late fourth millennium BC (SENNA-MARTINEZ, 1994e). Thus, the available evidence for the local intensive use of acorns indicates duration of at least two thousand three hundred years. This continuity is consistent with the classic tradition that attributes to the Lusitanians its use for bread making (Strabo, Geographika, III, 3, 7 in: GARCíA Y BELLIDo, 1978, p. 120) and that has been proved possible for the Iron Age galician castros (VÁZQUEZ VÁRELA, 1974-75; OLTVEIRA, QUEIROGA \& DINIS, 1991).

Data resulting from the study of animal bones coming from the Early/Middle Bronze Age occupation of Buraco da Moura de S. Romao shows that pastoralism ${ }^{8}$ was already well developed during this earlier phase (CARDOSO, SENNA-MARTINEZ \& VALERA, 1995, 1998) correlating well with the information derived

* Which Include predominantly Ovis aries but also with Bos taunts present. 
from pollen analysis and thus allowing us to extrapolate this information to the Late Bronze Age. Equivalent data is now available for some of the Beira Baixa sites (VILAÇA, 1995, p. 368-369) with the possible addition of barley, according to seed impressions found in pottery.

All of this means that the main subsistence elements present at the Late Bronze Age sites show a marked continuity to the ones we assume regionally (at least in Beira Alta) for the antecedent Early/Middle Bronze Age (SENNA-MARTINEZ, 1993b and 1993c).

The presence of moulds of bronze, clay and stone, together with slag fragments documents well the local production of tin bronze metal artefacts at all the excavated settlements of both regions. These attest to the local production in Beira Alta of bifacial double looped palstaves, unifacial single looped ones, socketed spearheads and awls, while for Beira Baixa sites only the production of awls is attested (VILAÇA, 1995, p. 326-327). To these types we can add, with some probability of their being locally made, the bronze fibulae and rings from the settlements of both regions as well as the bronze socketed sickles and the gold torques and bracelet from Senhora da Guia (GIL, et ah, 1989; SENNA-MARTINEZ, 1994a; SILVA, 1986, p. 165229, 233; SILVA, SILVA \& LOPES, 1984; TEIXEIRA, 1940; VILAÇA, 1995, p. 330).

The emergence of individual burials - suggested by the findings of Fonte da Malga (KALB \& HOCK, 1979) and Paranho (COELHO, 1925) together with the final abandonment of the megalithic necropoli ${ }^{9}-$ is a sure indication that changes are affecting the ideo$\log y$ as well.

\section{SOCIAL AND ECONOMIC STRUCTURES}

The economic system that emerges from the analysis of the available data for the Late Bronze Age Beira Alta and Beira Baixa Groups points to societies where the result of agricultural produce, pastoralism and wild fruits collecting (mainly acorns) is not enough by itself to support an economic growth capable to allow more than a small amount of wealth concentration and, accordingly, little social differentiation.

Since the basic subsistence staples of the economy were already in place from earlier times ${ }^{10}$, the only new economic factor introduced with the beginning of the Late Bronze Age seems to be the valorisation of local resources in tin and gold in Beira Alta with the addition of copper and lead in Beira Baixa. Thus, it can be argued that the regional mining of metals was the raison d'etre of the trading relations suggested by the circulation, adoption and local production of the Atlantic bronze models that constitute the overwhelming majority of the metal artefacts in use.

Two main communication routes probably connected these inland areas to the littoral lowlands of the Portuguese Estremadura (or, as we prefer to call it, the Atlantic Estremadura) and through it to the Atlantic network of contacts:

- One through the Lower Mondego's ria to the sites of Santa Olaia and maybe Conimbriga where the somewhat later Phoenician presence surely relates to the importance of those two sites as trading ports for the metals coming from inland (ROCHA, 1971; ALARCÃO \& PONTE, 1979; ALARCÃO \& ETIENNE, 1979; CORREIA, 1993; PEREIRA, 1986 and 1993);

- The other goes through the Tejo basin towards the ports of trade of its lower ria, two of them being the ancestors of the classical towns of Olisipo and Salacia (SENNA-MARTINEZ, 1995C).

Another route went inland and Southeast linking the Portuguese Beiras to the Spanish Estremadura and Andaluzia. It is the one that has the Southwest Stelae as marker and leads to Tartessos core area (RUIZ-GÁLVEZ \& GALAN DOMINGO, 1991; GALAN DOMINGO, 1994).

The small dimensions of the central habitat sites, the lack of differentiated house plans or equipment inside them" that could attest to special social status, the general similarity of the sites, all converge to make us believe that they were nodes of fairly similar importance in a settlement system where none of them occupied a dominant place.

Nevertheless the exceptional quality of bronzes such as the ones from the "deposit»' Guia (SILVA, SILVA \& LOPES, 1984) - namely the three cult-carts, the fúrcula or meat fork, the roasting spits and the seven hemispherical cups, with their possible cross-cultural connections (ALMAGRO-GORBEA, in press)-points to the existence of a stratified social structure with elites capable of absorbing such prestige items (SILVA, 1990).

We suggested before (SENNA-MARTINEZ, 1995a) a model for the populations of Beira Alta, during the

Still in use during most of the second millennium BC (SENNA-MARTINEZ, 1994e).

At least since the Calcolithic/Early Bronze Age transition (see SENNA-MARTINEZ, 1995c).

With the exception of bronze artefacts which, in the cases of known context, seem to come mainly from foundry areas or from hoards.

'A recent personal revision of the available data concerning the $\mathrm{S}$ a da Guia metallurgy points toward an interpretation as a «foundering area» as a better explanation. 
fourth to the second millennium BC, in which the development of social complexity was a slow process, principally because local resources only allowed a modest degree of intensification and interregional interaction.

We think that the transformation of this situation in the late second millennium $B C$ is the result of the catalysing effect of the establishment of the Atlantic network. This acted over societies having already a well-developed subsistence economy through the enhancement of the importance of the local mineral resources (in tin, gold, copper and lead). The local incipient elites were then able to supervise the production and circulation of metals and metal artefacts as means to ensure their status and control through a system of «wealth finance», as defined by Elizabeth Brumfiel and Timothy Earle (BRUMFIEL \& EARLE, 1987, p. 6).

The adoption and displaying of the «foreign symbols of power» introduced by the Atlantic sphere would have been particularly important for the establishment and enforcing of these local elites (BRUMFIEL \& EARLE, 1987, p. 3).

Since flint sickle blades and groundstone tools continue to be widely used, and field data shows that, as far as we can tell, no agricultural revolution can be correlated with the appearance of bronze implements, we think that most, if not all, of the metal artefacts present can be seen in this way. More than a direct influence in the production of subsistence the metal artefacts should be seen as «symbols of power» whose possession and display were crucial to the enforcement of the elites.

The concern with territory control, especially the natural routes, which we clearly detect in the location of the principal sites, is consistent with the necessity of the elites to control the goods' circulation.

A very important symbolic practice ${ }^{13}$ for the public display of the elite's power would have been the ritual meal or symposium. Besides the carts, meat forks and roasting spits from the sites of Senhora da Guia de Baiões, Moreirinha and Cachouça, the careful finishing and great variability - almost a personalization - of the small burnished drinking cups found in every known site bear witness to the early adoption of this practice. The bronze cups also found at Baiões constitute a more refined version of the earlier pottery ones.

The engraved decoration typical of the Baiões/ Santa Luzia pottery (SILVA, 1978; SENNA-MARTINEZ, 1989 and 1993d) as well as the «ornatos brunidos» we find in Beira Alta sites are applied mainly to carinated drinking cups and other vessels we suppose used for liquids manipulation. The inter and intra-site variability of its motives seems to constitute an early case of «emblemic differentiation)) (RENFREW, 1994, p. 163 ) thus eventually adding another element to the symbolic expression of status.

All the principal sites, through their control over space and circulation routes, would have to cooperate in order to assure that social reproduction as well as the circulation of goods, people and transumante flocks flowed unimpeded. Thus, we think that their defences as well as the metal military equipment found do not mean a permanent state of war but constitute the means of an «armed peace» warranting the maintenance of the circulation mechanisms fundamental for the existence of the elites and the economy.

In this way we think that matrimonial alliances can well have been one of the mechanisms of interaction between communities stimulating the circulation of metal goods (RUIZ-GÁLVEZ, 1994).

Such a structure of social regulation would make these communities very susceptible to contacts with other commercial networks capable of introducing other commodities that could be locally absorbed as prestige items. This is what seems to happen with the progressive interference of the Phoenician traders with the Atlantic network that began late in the IX century and also with previous Mediterranean exchanges attested according to what has been called a pre-colonial phase (ALMAGRO-GORBEA, 1991 ; AUBERT, 1992).

The early (c. $1200-900 \mathrm{BC}$ ) coexistence of bronze artefacts of «Atlantic origin» with arco serpeggiante and codo fibulae (SENNA-MARTINEZ, $1995 \mathrm{C}$; CARREIRA, in press.; VILAÇA, 1995), together with the equally early presence of iron blades both in Beira Alta and in Beira Baixa sites, bear witness to the first pre-colonial contacts with the «Mediterranean sphere of commerce».

In Atlantic Estremadura the arco serpeggiante fibula from Roça do Casal do Meio (SPINDLER, et al, 1973 -4.) together with the codo fibula from the Abrigo Grande das Bocas (CARREIRA, 1994, p. 81-83 and Est. XXXIII) and the iron blade fragments from Quinta do Marcelo ${ }^{14}$ establish the Tagus ria as the most likely entrance well before the establishing of the first Phoenician contacts.

All this helps to explain the presence of early Atlantic bronzes in Sardinia, Sicily and Italy, as well as the roasting spit of Atlantic type found in a tomb in Amatonte in Cyprus (COFFYN, 1985; COFFYN \& SION,

Of Mediterranean origin? Since we have the Beaker precedent (SHERRAT, 1987) it could be an older local practice reinforced by later contacts.

We thank Dr. Luís de Barros (Almada Municipal Museum) for this information. 
1993) that we can see, together with the early fibulae and iron blades of the Iberian Peninsula, as indicators of an early interface of the Atlantic and Mediterranean circulation networks.

The importance of the Phoenician presence in the rias of the Tagus and Mondego rivers, from the VIII century $\mathrm{BC}$ onwards, that recent archaeological work has revealed (AMARO, 1993; ARRUDA, 1993; BARROS, CARDOSO \& SABROSA, 1993; CARDOSO, 1990; CARDOSO \& CARREIRA, 1993; CORREIA, 1993; PEREIRA, 1986 and 1993) makes the Atlantic Estremadura an important turning plate for the trade with the inland metal producing areas (namely the Portuguese Beiras) and also explains the orientalizing influence on the inland Late Bronze Age settlements, the development of its principal «ports of trade», as well as the amazing concentration of late Atlantic bronzes found there (KALB, 1980a and 1980b).

\section{THE COLLAPSE}

The continuous development of the main sites in Atlantic Estremadura during the rest of the first millennium BC up to the Roman conquest contrasts sharply with what happens in the Beiras where the middle VI century BC seems to assist to a general collapse of the Late Bronze Age settlements till the Roman conquest sees to the reoccupation of some of them.

A social and economic structure based on a system of wealth finance such as the one we propose for Central Portugal Late Bronze Age communities would make them very vulnerable to any change in the exchange networks that they depended on in order to maintain it.

This is why we think the temporary collapse of the Mediterranean-Atlantic commerce in the middle sixth century $\mathrm{BC}$ is one of the reasons behind the collapse (at about that time) of the Late Bronze Age communities of Beira Alta and Beira Interior (SENNA-MARTINEZ, 1995C; VILACA, 1994).

While the temporary collapse of the maritime trade routes that sustained the social systems of the Portuguese Beiras will affect them beyond repair, other regions of the Iberian Peninsula with more developed economic and social systems will soon recover and see the first real urban settlements appear together with the first State formations.

Such seems to be the case of the Atlantic Estremadura where a more developed agriculture, probably including the first local productions of olive oil and wine ${ }^{15}$, will sustain the economy of the local «ports of trade» and assist their development during the Iron Age.

The analysis of the data available for the Portuguese Beiras Bronze Age seems to support the idea of a temporary development of more permanent settlement types during the Late Bronze Age followed by a return to the more mobile ways of life characterising the regional earlier periods contrasting with the continuity of development of urban structures in the Atlantic Estremadura.

This model agrees well with the classic description of the Lusitânia by Pliny the Elder (GUERRA, 1995) divided between a mountainous interland without oppida (i.e. non urban) and a more complex and developed Atlantic littoral with the towns of Talabrica, Aeminium, Coniumbrica, Collipo, Eburobritium, Olisipo and Scallabis.

Also the description by Strabo of the Lusitanian highlanders' ways of life (GARCíA Y BELLIDO, 1978: 120), namely ovicaprids husbandry, the use of acorns to make bread, of butter instead of olive oil and of beer instead of wine, together with the late use of bronze lance heads is consistent with the archaeological record for the Bronze Age. Also the loose type of polities described agrees well with what we propose for the Late Bronze Age communities of the Portuguese Beiras and more so with what we would expect after the collapse of the VI century BC.

So we propose as a working hypothesis that what we see reflected in the archaeological record for the Portuguese Beiras Bronze Age is the material correlate for the ethnogenesis of the core area of what will be called, in classic times, the Lusitânia.

Once interrupted the process of social stratification it will take the Roman conquest to make the interior regions of central Portugal witness the late and soon doomed rallying of the Lusitanian tribes.

\section{REFERENCES}

ALARCÃO, A. M. \& PONTE, S. (1979) - Trouvailles diverses, Fouilles de Conimbriga, VU, Paris, Boccard

ALARCÃO, J. \& ETIENNE, R. (1979) - Conclusions générales, Fouilles de Conimbriga, VII, Paris, Boccard

ALMAGRO-GORBEA, M. (1991) - El mundo orientalizante en la Península Ibérica, Atti dei II Congreso Internazionale di studi Fenici e Punici, 2, Roma, Consiglio Nazionale délie Ricerche, p.573-599

ALMAGRo GORBEA, M. (in press) - El Deposito da Sra. da Guia y el Bronce Atlântico Português, Actas II Colóquio Arqueol. Viseu, Viseu

AMARO, C. (1993) - Vestígios materiais orientalizantes do Claustro da Sé de Lisboa, Estudos Orientais IV. Os Fenícios no território português, Lisboa, p. 183-192

${ }^{15}$ As the Vitis pips found at the orientalizing site of Almaraz in the Tagus ria seem to imply (BARROS, in press.). 
ARRUDA, A. M. (1993) - A ocupação da Idade do Ferro da Alcáçova de Santarém no contexto da expansão fenícia para a fachada atlântica peninsular, Estudos Orientais IV. Os Fenícios no território português, Lisboa, p. 193-214

AUBERT, C. (1992) — La période pré-phénicienne en Péninsule Ibérique: relations avec la Méditerranée Centrale», Mélanges de Casa de Velazquez, XXVIII (1), p. 7-18.

BARROS, L. (in press)- Presença da Vinha no Povoado do Almaraz.

BARROS, L.; CARDOSO, J. L. \& SABROSA, A. (1993) - Fenicios na margem sul do Tejo. Economia e integração cultural do povoado do Almaraz - Almada, Estudos Orientais IV. Os Fenícios no território português, Lisboa, p.143-181

BRUMFIEL, E. M. \& EARLE, T. K. (1987) - Specialization, exchange, and complex societies: an introduction», in: E.M. BRUMFIEL \& T. K. EARLE (Eds.), Specialization, exchange, and complex societies, Cambridge University Press, Cambridge, p. $1-9$

CARDOSO, J. L. (1990) - A presença oriental no povoamento da I Idade do Ferro na região ribeirinha do Estuário do Tejo», Estudos Orientais 1. Presenças orientalizantes em Portugal da Pré-História ao período romano, Lisboa, p. 119-134

CARDOSO, J. L. 1995a. «Os Povoados do Bronze Final a Norte do Estuário do Tejo», AAVV, A Idade do Bronze em Portugal, Lisboa, IPM, p. 126

CARDOSO, J. L. (1995b) - O povoado do Bronze Final da Tapada da Ajuda, AAW, A Idade do Bronze em Portugal, Lisboa, IPM, p. 48

CARDOSO, J. L. \& CARREIRA, J. R. (1993) — Le Bronze Final et le Début de l'Age du Fer dans la région riveraine de l'estuaire du Tage», in: Mediterrâneo, 2, p. 193-206

CARDOSO, J. L.; SENNA-MARTINEZ, J. C. \& VALERA, A. C. (1995) Um indicador económico para o Bronze Pleno da Beira Alta: A fauna de grandes mamíferos da Unidade Estratigráfica 4 da 'Sala 20' do Buraco da Moura de S.Romão (Concelho de Seia), Actas da 3" Reunião do Quaternário Ibérico, Coimbra, 27 de Setembro a 1 de Outubro de 1993, Universidade de Coimbra, p. 457-460

CARDOSO, J. L.; SENNA-MARTINEZ, J. C. \& VALERA, A. C. (1998) Aspectos da Economia Alimentar do Bronze Pleno da Beira Alta: A fauna de grandes mamíferos das «Salas 2 e 20» do Buraco da Moura de S. Romão (Seia), Trabalhos de Arqueologia da EAM, 3/4, Lisboa, Colibri, 1995/1996, p. 253-261.

CARREIRA, J. R. (1994) - A Pré-história Recente do Abrigo Grande das Bocas (Rio Maior), Trabalhos de Arqueologia da EAM, 2, Lisboa, Colibri, p. 47-144

CARREIRA, J. R. (in press) - O sítio do Bronze Final de Monte Airoso, Penedono, Trabalhos de Arqueologia da EAM, 3, Lisboa, Colibri.

COELHO, J. (1925)-A Nécropole do Paranho, Ed. Autor, Viseu.

COELHO, J. (1947) - Alguns objectos do bronze da Beira Alta (Contribuição para o estudo do Bronze peninsular), Beira Alta, $6(3-4)$, p. $209-226$

COFFYN, A. (1985) - Le Bronze Final Atlantique dans la Péninsule Ibérique, Paris, Diffusion du Boccard

COFFYN, A. \& SION, H. (1993) - Les relations atlanto-méditerranéennes. Eléments pour une révision chronologique du Bronze final atlantique, Mediterrâneo, 2, p. 285-293

CORREIA, V. H. (1993) - Os materiais pré-romanos de Conimbriga e a presença fenícia no baixo vale do Mondego, Estudos Orientais IV. Os Fenícios no território português, Lisboa, p. 229-283

GALAN DOMINGO, E. (1994)_Estelas, paisaje y territorio en el Bronce Final del Suroeste de la Península Ibérica, Madrid, Editorial Complutense, «Complutum Extra», 3

GARCÍA E BELLIDO, A. (1978) - España y los españoles hace dos mil años segíin la «Geografia» de Strábon, Espasa-Calpe, Madrid, 6". Ed.

GIL, F.B., et al, (1989) — Produções metalúrgicas do Bronze Final do Cabeço do Crasto de S. Romão, Seia: uma primeira análise», Actas do I Colóquio Arqueológico de Viseu, Viseu, p. 235-48.
GILMAN, A. (1987) - Unequal development in Copper Age Ibéria», in: E. A. BRUMFIEL \& T. K. EARLE (eds.), Specialization Exchange and Complex Societies, Cambridge University Press, Cambridge, p. 22-9

GUERRA, A. (1995) - Plínio-o-Velho e a Lusitânia, Lisboa, Colibri

HASSAN, F. A. (1981)-Demographic Archaeology, New York, Academic Press.

JANSSEN, CR. (1985) - História da vegetação, in: S. DAVEAU. Ed., Livro-Guia da Pré-Reunião. Glaciação da Serra da EstrelaAspectos do Quaternário da Orla Atlântica, G.T.P.E.Q.G.E.T.Q., Lisboa, p. 66-72

JANSSEN, CR. \& WOLDRINGH, RE. (1981) - A preliminary radiocarbon dated pollen sequence from the Serra da Estrela, Portugal, Finisterra, XVI, 32, p.299-309

KALB, P. (1974-7) —Uma data C-14 para o Bronze Atlântico, O Arqueólogo Português, Série III, 7-9, p. 141-4.

KALB, P. (1978) — Senhora da Guia, Baiões. Die Ausgrabung 1977 auf einer Hohensiedlung der Atlantischen Bronzezeit in Portugal», in: Madrider Mitteilungen, 19, p. 112-38

KALB, P. (1980a) - Zur Atlantischen Bronzezeit in Portugal», Germania, 58, p.25-115

KALB, P. (1980b) - O «Bronze Atlântico» em Portugal, Actas do Seminário de Arqueologia do Noroeste Peninsular, Vol. I, Guimarães, p.113-120 + 14 mapas extra-texto.

KALB, P. \& HÖCK, M. (1979) - Escavações na necrópole de mamoas 'Fonte da Malga' — Viseu, Portugal, Beira Alta, 38(3), p. 593-604

KNAAP, W. O. \& JANSSEN, CR. (1991) - Utrecht on the RocksSerra da Estrela (Portugal), XV Peat Excursion of the Syst.Geobo. Institute, University of Bern, Part II, Laboratory of Paleobotany and Palynology, State University of Utrecht/The Netherlands.

KNAAP, W. O. \& VAN LEEUWEN, J. F. N. (1994) - Holocene vegetation, human impact, and climatic change in the Serra da Estrela, Portugal, in: A. F. LOITER \& B. AMMANN, (Eds.), Festschrift Gerhard Lang, «Dissertationes Botanicae», 234, p.497-535

LOPES, A. B. (1993) - A Cerâmica do Castro da Senhora da Guia (Baiões). Tecnologia e Morfotipologia, Dissertação de Mestrado em Arqueologia apresentada à Faculdade de Letras da Universidade do Porto, policopiado.

MARTINS, A. F. (1940) - O esforço do homem na bacia do Mondego, Coimbra, Edição do Autor

NARROL, R. (1962) - Floor area and settlement population, American Antiquity, 27, p.587-589

OLIVEIRA, F., QUEIROGA, F. \& DINIS, A.P. (1991) — O pão de bolota na cultura castreja, Paleoecologia e Arqueologia, II, Vila Nova de Famalicão, p. 251-268

PEREIRA, I. (1986) - Castro de Santa Olaia, Informação Arqueol., 7, p.29-33

PEREIRA, I. (1993) - Figueira da Foz. Santa Olaia, Estudos Orientais IV. Os Fenícios no Território Português, Lisboa, p. 285-304

RENFREW, C. (1994) - The identity of Europe in Prehistoric Archaeology, Journal of European Archaeology, 2.2, p.153-173.

ROCHA, A. S. (1971) —Estações Pré-Romanas da Idade do Ferro nas vizinhanças da Figueira, Imprensa da Universidade, Coimbra.

RUIZ-GÁLVEZ, M. (1994) — The bartered bride. Goldwork, inheritance, and agriculture in the Late Prehistory of the Iberian Peninsula, Jourrnal of European Archaeology, 2(1), p.50-81

RUIZ-GÁLVEZ, M. \& GALAN DOMINGO, E. (1991) — Las estelas del Suroeste como hitos de Gas ganaderas y rutas comerciales, Trabajos de Prehisloria, 48, p. 257-273

SENNA-MARTINEZ, J. C. (1984) - O Monumento no.3 da necrópole dos Moinhos de Vento. Arganil: a campanha 1984, Clio/Arqueologia , 1. p. 213-216

SENNA-MARTINEZ, J. C. < 1986) - Cabeço do Crasto - S. Romão. I Campanha. Informação Arqueológica, 7, p.44-46. 
SENNA-MARTINEZ, J.C. (1989) - Pré-História Recente da Bacia do Médio e Alto Mondego: algumas contribuições para um modelo sociocultural, Tese de Doutoramento em Pré-História e Arqueologia, Faculdade de Letras de Lisboa, 3 Vols., policopiado.

SENNA-MARTINEZ，J. C. (1993a) - Apresentação: 'Trabalhos de Arqueologia na Bacia do Médio e Alto Mondego - 19821992, Trabalhos de Arqueologia da EAM, 1, Lisboa, Colibri, p. $1-7$

SENNA-MARTINEZ, J. C. (1993b) - A ocupação do Bronze Pleno da 'Sala 20' do Buraco da Moura de São Romão, Trabalhos de Arqueologia da EAM, 1, Lisboa, Colibri, p. 55-76

SENNA-MARTINEZ, J. C. (1993c) - Duas contribuições arqueométricas para o estudo do Bronze Antigo/Médio do Centro e Noroeste de Portugal, Trabalhos de Arqueologia da EAM, 1, Lisboa, Colibri, p. 77-91

SENNA-MARTINEZ, J. C. (1993d) - O Grupo Baiões/Santa Luzia: contribuições para uma tipologia da olaria, Trabalhos de Arqueologia da EAM, 1, Lisboa, Colibri, p. 93-123

SENNA-M.ARTINEZ, J. C. (1994a) — Entre Atlântico e Mediterrâneo: algumas reflexões sobre o Grupo Baiões/Santa Luzia e o desenvolvimento do Bronze Final peninsular, Trabalhos de Arqueologia da EAM, 2, Lisboa, Colibri, p. 205-222.

SENNA-MARTINEZ, J. C. (1994b) - Notas para o estudo da génese da Idade do Bronze na Beira Alta: o fenómeno campaniforme, Trabalhos de Arqueologia da EAM, 2, Lisboa, Colibri, p. $163-190$

SENNA-MARTINEZ, J. C. (1994c) - O habitat do Bronze Final do Outeiro dos Castelos de Beijos (Carregal do Sal): a campanha 1(993), Trabalhos de Arqueologia da EAM, 2, Lisboa, Colibri, p. $243-252$

SENNA-MARTINEZ, J. C. (1994d) - Subsídios para o estudo do Bronze Pleno na Estremadura Atlântica: (1) A alabarda de tipo «Atlântico» do Habitat das Baútas (Amadora), Zephyrus, XLVI-XLVII, p.149-170

SENNA-MARTINEZ, J. C. (1994e) - Megalitismo, habitat e sociedades: a Bacia do Médio e Alto Mondego no conjunto da Beira Alta (c.5200- -3000 BP), Actas do Seminário «O Megalitismo no Centro de Portugal», «Estudos Pré-Históricos», 2, Viseu, p. $15-29$

SENNA-MARTINEZ, J. C. (1995a) - The Late Prehistory of Central Portugal: a first diachronic view, in: Katina T. Limos (ed.), The Origins of Complex Societies in Late Prehistoric Iberia, Ann Harbour (Michigan), International Monographs in Prehistory, «Archaeological Series», 8, p. 64-94

SENNA-MARTINEZ, J. C. (1995b) — O Povoado do Cabeço do Crasto de S. Romão, A Idade do Bronze em Portugal, Discursos de Poder, Lisboa, IPM, p. 61-65

SENNA-MARTINEZ, J. C. (1995c) - No Alvorecer da Vida Urbana: Bronze Final e presenças orientalizantes no Centro de Portugal, Portugal e o Mundo, do Passado ao Presente, «Actas do 1." Curso de Verão de Cascais», Cascais, Câmara Municipal de Cascais, p. 63-84

SENNA-MARTINEZ, J. C. (1995d) - O povoamento calcolítico da bacia do Médio e Alto Mondego: algumas reflexões», Origens, estruturas e relações das culturas calcoliticas da Península Ibérica. Actas das I.Jornadas Arqueológicas de Torres Vedras. 3-5 de Abril de 1987, Lisboa, IPPAR, «Trabalhos de Arqueologia», 7, p. 83-100

SENNA-MARTINEZ, J. C. (1996) - The symbolism of power in Central Portugal Late Bronze Age Communities, Máthesis, 5, p. $163-175$

SENNA-MARTINEZ, J. C. (1998a) — Produção, ostentação e redistribuição: estrutura social e economia política no Grupo Baiões/Santa Luzia», in: S. O. JORGE (ed.), Existe uma Idade do Bronze Atlântica?, Lisboa, IPA, p. 218-230

SENNA-MARTINEZ, J. C. (1998b) - O habitat do Bronze Final do Outeiro dos Castelos de Beijos (Carregal do Sal): a campanha 2(994), Trabalhos de Arqueologia da EAM, 3/4, Lisboa, Colibri, $1995 / 1996$, p. $285-292$
SENNA-MARTINEZ, J. C. (in press) - A Estatística na Análise dos Materiais Arqueológicos: alguns exemplos», Actas do Seminário «A Actualidade da Estatística em Portugal», Universidade Lusíada, Lisboa, Abril de 1994

SENNA-MARTINEZ, J. C. \& COELHO, N. (1994) - Castro de S. Cosme», Informação Arqueológica, 9, p. 55-56

SENNA-MARTINEZ, J. C; GARCIA, M. F. \& ROSA, M. J. (1984)Contribuições para uma tipologia da olaria do megalitismo das Beiras: olaria da Idade do Bronze (I), Clio/Arqueologia, 1, p. $105-138$

SENNA-MARTINEZ, J.C.; GUERRA, A \& FABIÃO, C. (1986) - Cabeço do Crasto, São Romão, Seia. A Campanha 1.(985), Catálogo da Exposição Temporária - FIAGRIS/86, UNIARCH/GHAS, Lisboa.

SENNA-MARTINEZ, J. C. \& NUNES, T. S. (1993) - A ocupação do Bronze Final do Outeiro dos Castelos (Beijos): uma primeira análise, Trabalhos de Arqueologia da EAM, 1, Lisboa, Colibri, p. $137-141$

SENNA-MARTINEZ, J. C; ROCHA, L. \& RAMOS, R. P. (1993) A ocupação do Bronze Final da Malcata (Carregal do Sal): uma primeira análise, Trabalhos de Arqueologia da EAM, 1, Lisboa, Colibri, p.149-154.

SENNA-MARTINEZ, J. C. \& VALERA, A. C. (1995) - O Buraco da Moura de S. Romão, A Idade do Bronze em Portugal, Discursos de Poder, Lisboa, IPM, p. 50-53

SENNA-MARTINEZ, J. C; VALERA, A. C. \& CARREIRA, J. R. (1993) A Pré-História Recente, in: G. S. CARVALHO, A.B. FERREIRA \& J. C. SENNA-MARTINEZ (eds.), O Quaternário em Portugal, Balanço e Perspectivas, Lisboa, Colibri, p. 185-198

SENNA-MARTINEZ, J. C; VALERA, A. C; TEIXEIRA, A. C. \& VENTURA, J. M. Q. (1993) - A ocupação do Bronze Final do Buraco da Moura de São Romão, Trabalhos de Arqueologia da EAM, 1, Lisboa, Colibri, p. 125-135

SENNA-MARTINEZ, J. C; NASCIMENTO, A. Q.; CARVALHO, A. F. \& ALMEIDA, F. S. (1993b)__A ocupação do Bronze Final do Cabeço do Cucão, Pedra Cavaleira (Silgueiros, Viseu): uma primeira análise, Trabalhos de Arqueologia da EAM, 1, Lisboa, Colibri, p. 143-147

SHERRATT, A. (1987) - Cups That Cheered, in W. H. WALDREN \& R. C. KENNARD (eds.), Bell Beakers of the Western Mediterranean, Oxford, BAR International Series 331(i) p. $81-114$

SILVA, A. C. F. (1986)-A Cultura Castreja no Noroeste de Portugal, Paços de Ferreira, Museu Arqueológico da Citânia de Sanfins.

SILVA, A. C. F. (1990) - Influências orientalizantes na formação da cultura castreja do Noroeste peninsular, Estudos Orientai I. Presenças orientalizantes em Portugal da Pré-História ao período romano, Lisboa, p. 135-155.

SILVA, A. C. E; SILVA, C. \& LOPES A. B. (1984) - Depósito de fundidor do final da Idade do Bronze do Castro da Senhora da Guia (Baiões, S.Pedro do Sul, Viseu), Lucerna-Home-nagem a D.Domingos Pinho Brandão, Porto, p. 73-109.

SILVA, Celso T. (1978) Cerâmica típica da Beira Alta, Actas III Jornadas de Arqueologia, Lisboa, p. 185-196.

SILVA, Celso T. (1979) -O Castro de Baiões (S.Pedro do Sul), Beira Alta, XXXVIII(3), p. 509-531.

SILVA, Celso T, CORREIA, A. \& VAZ, J. L. I. (1984) -Monte de Sta. Luzia, Informação Arqueológica, 4, p.124-125.

SILVA, Celso T.; CORREIA, A. \& VAZ, J. L. I. (1985) - Castro de S. Luzia - 1982, Informação Arqueológica, 5, p. 145 . ...

TEIXEIRA, C. (1940) - Molde de fundição para machados de bronze de duplo anel, Trabalhos de .Antropologia e.Etnologia, 9 (1-2), p. $126-130$

VALERA, A. C. (1992) - Castro de Santiago (Figueiró da Granja) As campanhas de 1990 e 1991, Gabinete de Arqueologia de Fornos de Algodres, Câmara Municipal de Fornos de Algodres.

VALERA, A. C. (1993) - Diversidade e relações inter-regionais no povoamento calcolítico da Bacia do Médio e Alto Mondego, Trabalhos de Antropologia e Etnologia, 34 (1-2), p. 153-176 
VALERA, A. C. (1994) - Pré-História Recente no Concelho de Fornos de Algodres (Guarda): resultados das escavações e prospecções de 1992/93, Trabalhos de Arqueologia da EAM, 2, Lisboa, Colibri, p. 135-162.

VALERA, A.C. (1997) - O castro de Santiago (fornos de Algodres, Guarda): aspectos da calcolitização da Bacia do Alto Mondego, Lisboa, EAM, «Textos Monográficos», 1.
VAZ, J. L. I. (in press) - «4 datações C14 para o Bronze Final português», Actas II Colóquio Arqueológico de Viseu, Viseu.

VAZQUEZ VARELA, J. M. (1974-75) - Hallazgos de bellotas en el castro de Vixil: Reflexiones sobre la cultura castrena, Boletin de la Comision de Monumentos de Lugo, 9 (81-84), p. 195-198

VILAÇA, R. (1995)-Aspectos do povoamento da Beira Interior (Centro e Sul) nos finais da Idade do Bronze, Lisboa, IPPAR, «Trabalhos de Arqueologia», 9, 2 vols. 